\title{
A BWS Application to Identify Factors Affecting User Preferences for Parking Choices at University Campuses*
}

Identificación de factores influyentes en la elección de parqueaderos en universidades a través de MaxDiff

Received: October 29, 2018 | Accepted: September 19, 2019 | Published: February 24, 2020

\section{Mauricio Orozco-Fontalvo ${ }^{\mathrm{a}}$}

Universidad Militar Nueva Granada, Bogotá, Colombia.

ORCID: 0000-0003-0514-4647

\section{Sheila Martínez}

Universidad de la Costa, Barranquilla, Colombia.

ORCID: 0000-0002-8014-9088

\section{Julián Arellana}

Universidad del Norte

ORCID: 0000-0001-7834-5541

\section{Laura Vega}

Universidad del Norte, Barranquilla, Colombia.

ORCID: 0000-0002-9869-4578

${ }^{*}$ Review article.

${ }^{a}$ Corresponding author. Email: mauricio.orozco@unimilitar.edu.co

DOI: $\underline{\text { https://doi.org/10.11144/Javeriana.iyu24.aifa }}$

\section{How to cite this article:}

M. Orozco-Fontalvo, S. Martínez, J. Arellana, and L. Vega, "A BWS application to identify factors affecting user preferences for parking choices at university campuses," Ing. Univ., vol. 24, 2020. https://doi.org/10.11144/Javeriana.iyu24.aifa 


\section{Abstract}

Parking around university campuses has become a major issue in recent decades because of nearby congestion impacts. Objective: To determine the factors influencing parking lot selection, which is crucial to propose adequate parking demand management strategies. Materials and Methods: We evaluate different attributes using a best-worst scaling survey applied at Universidad de la Costa (CUC), Colombia. Using discrete choice modeling techniques, we identified the extent to which selected infrastructure attributes influence parking behavior. Results: Security and cover (roof) availability are the most relevant attributes of parking choice in the case study. Conclusions: Based on our results, we strongly recommend implementing a dynamic pricing rate, roof pricing, removing "reserved spots" and investing in security.

Keywords: best-worst scaling, multinomial logit, parking choice, parking management

\section{Resumen}

El parqueo en las universidades o sus alrededores se ha convertido en un problema importante, debido a la falta de espacio y su impacto en la congestión de vías cercanas. Objetivo: Determinar los factores que influyen en la elección de parqueaderos, con el fin de proponer estrategias adecuadas para la gestión de estos. Materiales y métodos: Se evaluaron diferentes atributos usando el método de escalamiento por máximas diferencias a través de una encuesta aplicada en la Universidad de la Costa (CUC), Colombia. Luego, a través de modelos de elección discreta, se identificó el grado en que diferentes características de infraestructura determinan la elección del sitio de parqueo. Resultados: La seguridad y la disponibilidad de parqueaderos cubiertos son los atributos más relevantes en este caso. Conclusiones: Con base en los resultados obtenidos, se recomienda implementar políticas de tarifa dinámica, diferenciar precios de parqueaderos cubiertos y descubiertos, eliminar los "parqueaderos reservados" e invertir en tecnología que mejore la seguridad.

Palabras clave: escala maxdiff, logit multinomial, elección de parqueaderos, gestión de parqueadero 


\section{Introduction}

Study and work are the principal travel purposes in many cities. Universities are among the leading daily destinations of commuters, i.e., UC Berkeley is one of the largest employers in the San Francisco Bay Area, generating approximately 50,000 daily trips to the campus [1]. An increasing flow of commuters distributed across different modes of transportation (e.g., bus, walking, or car) often congest the infrastructure around university campuses. Those members of the campus population who choose the car as their travel mode congest the streets and require additional infrastructure upon their arrival to university parking lots. Because transportation facilities are not sufficient to serve the number of commuters traveling by car, cars driving around university campuses looking for parking spaces are not rare and generate additional environmental pollution and noise disturbance.

Mobility issues around university campuses arise with population and university growth. Due to the extensive resources and time required to build infrastructure, it is not possible to embrace the total car demand around universities without taking additional measures to avoid congestion. Different authors worldwide [2]-[5] have proposed several policies (such as parking lot regulation through pricing) and infrastructure interventions to address mobility issues around universities.

The results of these studies suggest changing how the use of vehicles in university campuses is controlled to reduce congestion while considering environmental and social sustainability criteria [6]. At Bilbao University, a study revealed that improving the supply of public transportation (in terms of the amount, frequency, and pricing) would reduce the number of commuters using private vehicles, encouraging them to shift towards public transportation and thereby reduce campus congestion [7]. Fourteen years ago, UC Berkeley implemented the Class Ecopass program, which provides free unlimited rides to its staff and students. This program has reduced students' driving to campus by $50 \%$.

In the Colombian context, universities are facing parking issues as well. A mobility study for Universidad de Antioquia in Medellin proposed plate restrictions on access to university parking lots. However, after a few months, the measure proved to be unhelpful for reducing traffic around the campus, and the demand for parking services continued to rise [8]. At the Universidad del Norte in Barranquilla, a study determined that parking spaces constitute a relevant variable in the mobility analysis and suggested that preassigned parking spaces for administration staff reduce efficiency in the use of parking lots due to the low occupancy rate of those spaces [9]. Rationalizing car use at universities should take into account price elasticity in the demand of different users (i.e., staff, academics).

Parking congestion leads to a belief that more spaces are needed, thereby increasing the cost of parking lot infrastructure. Determining the suitable number of parking spaces is crucial to prevent oversized lots and excess annual costs [10]. In fact, it has been proven that providing fewer parking spaces while offering different incentives (such as a cup of coffee for shared rides or one dollar for not using the car for a week) can improve accessibility, consequently 
increasing the use of public transportation and reducing solo driving [1].

Before defining or implementing new parking policies, it is crucial to identify the factors influencing the mode choice, the users' parking behavior, and the time spent in the parking lot, among others [11]-[13].

In the literature focused on this topic, different methodologies are used to identify the influence of several attributes in some specific behavior. One of those available methodologies is the best and worst scaling (BWS) technique. Jordan Louviere proposed this method in 1987, considering the question of what he could do with information on the "least preferred" item from a choice set, in addition to the traditional "most preferred "item" [14]. The BWS offers a cost-efficient way to obtain more information from a respondent and a way of evaluating models of choice processes.

Three different types of BWS can be found in the literature. Case 1 refers to the object case, where stand-alone attributes are presented and evaluated by the interviewee. The respondent chooses the best and the worst attribute. Case 2, called the profile case, presents a study object described by different attributes one at a time, and respondents choose the best and worst attributes within a profile. Case 3 , named the multi-profile case, bundles all attributes into a product/service, and respondents choose between profiles, similar to a ranking task in a discrete choice experiment.

The BWS methodology generates results that are more practical for the analysis; nevertheless, it may have some disadvantages [15], i.e., it takes longer to obtain the final results, mostly when the analysis involves a large population or quite a long list of attributes. In addition to the above disadvantage, BWS tasks are easier for people to respond to in comparison to other methodologies, such as monadic rating and paired comparisons [16]. Larrañaga [17] recently found that the BWS is a suitable technique for obtaining the relative importance of attributes. They used the BWS approach to obtain built environment barriers to promote walkable neighborhoods. In fact, a BWS online survey applied to an elderly group to obtain its preferences for exercise programs suggests that it is not a problematic survey type. Its results were analyzed by modeling each attribute with its correspondence level using MNL [18]. Additionally, an application for obtaining users' preferences in food labeling attributes proved that in comparison to another method such as direct ranking, BWS improved individual choice predictions and generated a more consistent dominance ordering of attribute importance [19]. Balbontin et al. obtained similar results in their BWS application to find the essential attributes in a residential location context [20].

In this paper, we apply the BWS technique to determine the factors influencing parking choice at universities. We use the Universidad de la Costa campus in Barranquilla, Colombia, as a case study. In a literature review, we did not find any references applying the BWS to understand user parking preferences at college or cities, highlighting the novelty of this investigation into parking behavior. Given the long list of attributes that could affect the user selection of a parking lot, it is difficult to select suitable attributes for a stated preference survey a priori. Therefore, we envisage the BWS technique as a step prior to a stated preference (SP) experiment. BWS can be useful for defining which attributes are the most relevant to explain behavior. With the BWS findings, we identified a list of attributes for 
further research with SP techniques to obtain user willingness to pay for the most influential factors. The structure of the paper consists of three sections. First, we describe the methodology of the application of the BWS survey, including the experimental design and some criteria for the application of the case of study. Then, we present the modeling results and provide a descriptive discussion analyzing the meaning of each model. Finally, we provide the main conclusions and highlight the potential for future research.

\section{Materials and methods}

The purpose of this paper is to study the most influential attributes for parking behavior at the Universidad de la Costa campus, located in the northern zone of the city of Barranquilla in Colombia. We seek to propose some demand management strategies based on the results found for users' preferences with the aim of controlling and reducing the continually growing demand for parking and relieving the congestion that afflicts campus sustainability. To understand the parking behavior of people traveling to the Universidad de la Costa campus, it is critical to know that Barranquilla is a coastal city located in the Caribbean region of Colombia. The city has an average temperature of $31^{\circ} \mathrm{C}$ with relative humidity between 75 and $95 \%$ and a citizen security index of 0.58 (on a scale from 0 to 1 , which locates it in 5 th place among the six major cities of the country) [21]. The weather and security conditions of the city affect commuters' willingness to walk and to use public transportation.

It was decided to use the BWS methodology due to its practicality and the ease of obtaining survey responses when evaluating a large number of attributes. BWS represents a choice elicitation method that can be used to analyze asymmetry between the characteristics that impede and promote parking choice. There are several psychology studies concluding that an asymmetry exists in the way people handle positive and negative phenomena, which is called positive-negative asymmetry [22]-[24].

Positive-negative asymmetry is also in line with prospect theory [25]. According to this theory, individuals make decisions based on the potential value of losses and gains, and the value of losses outweighs the value of gains [17].

We performed three different activities to complete the study. First, we inventoried all the parking lots available on the campus to characterize the parking supply. This activity was limited to the parking lots within the university's campus and those available within a threeblock radius. Within the scope of this activity, we counted the parking lots and measured pavement conditions, cover availability, demarcation, slope, pedestrian sidewalks, access control, pricing rate and distance/time to the universities' buildings.

The second activity focused on evaluating parking demand. The scope of this activity included estimating occupancy levels, parking turnover (defined as "the ratio of the total number of parked vehicles accommodated during a given period in a specified area to the total number of parking spaces in that area" [26]) and the variation in demand throughout the day and identifying the peak hours. In this activity, we applied the license plate method 
during four consecutive days (from Wednesday to Saturday).

The third activity involved BWS survey administration to elicit user parking preferences. This activity comprised a sequential design process to obtain the BWS survey instrument along with the data gathering and the econometric analysis. The design process included the definition of the attributes for studying the behavior, the experimental survey design, and participant selection. After designing the instrument, we applied the survey to two groups of respondents who currently park within and outside the campus. Then, we set the database and proceeded with model estimation and analysis.

\section{Definition of the attributes for study}

To define the list of attributes that may affect users' parking decisions, we reviewed some similar cases and complemented the study case particularities found in the inventory of parking spaces (activity 1). We established different attribute levels to evaluate each attribute's importance (see Table 1) to the parking behavior. These levels were defined first through focal groups, where we interviewed parking lot users regarding the time spent while parking $(\mathrm{C}$ and $\mathrm{D})$ and second city statistics (A, B and I). The other levels are related to infrastructure and were defined based on parking lot conditions in the city. In total, we identified eight attributes with two or three levels.

Table 1. Attributes and attribute levels

\begin{tabular}{|c|c|}
\hline Attribute & Levels \\
\hline \multirow{2}{*}{ Vehicle security (a) } & One damage or theft to the vehicle every month (in the area) \\
\hline & One damage or theft to the vehicle every three months (in the area) \\
\hline \multirow{2}{*}{ User safety (b) } & One robbery registered every month around the parking zone \\
\hline & One robbery registered every three months around the parking zone \\
\hline \multirow{2}{*}{ Walking time (c) } & The parking space is a 1 - 5 minute walk from the destination \\
\hline & The parking space is more than a 5 minute walk from the destination \\
\hline \multirow{3}{*}{ Circulation time (d) } & Time finding available parking space is 3 minutes or less \\
\hline & Time finding available parking space is between $3-6$ minutes \\
\hline & Time finding available parking space is more than 6 minutes \\
\hline \multirow{2}{*}{ Pedestrian (f) } & No sidewalk available \\
\hline & Sidewalks available \\
\hline \multirow{2}{*}{ Cover availability $(\mathrm{g})$} & Roof coverage for parking spaces: $100 \%$ to $55 \%$ of parking lots \\
\hline & There is no element of protection against sunshine or rain \\
\hline \multirow{2}{*}{ Demarcation (h) } & $\begin{array}{l}\text { No demarcation: It is hard to recognize the parking space and identify } \\
\text { circulation paths }\end{array}$ \\
\hline & With demarcation: Parking space signaling is appropriate \\
\hline \multirow[t]{2}{*}{ Parking fare (i) } & Free to USD 0.5/hour or fraction - USD 3 all day \\
\hline & USD $0.7 /$ hour or fraction - USD 4 all day \\
\hline
\end{tabular}

Source: Authors own elaboration. 


\section{Survey design}

We decided to use a face-to-face survey to avoid possible misinterpretations of the attribute level phrasing. The survey contained two sections. The first part gathered socioeconomic variables such as gender, age, role in the university (Student or Staff), household income (less than USD 720-more than USD 721), and socioeconomic class (upper, middle and lower). Neighborhood socioeconomic status is a system created by the Colombian government in which residential units are classified according to their physical characteristics and environment so that a differential cost can be charged for public services [27].

The second part of the survey dealt with the BWS application. There are three different BWS cases, depending on the complexity of the attributes under study.

The case presented to the respondents in this study was Case 2 - Profile Case [28]. Respondents had to choose the attribute that determines their election to park or not to park within the campus by evaluating a set of given options. Additionally, they had to identify the least relevant attribute of the list, one which they did not consider at all in their parking decision. The theoretical explanation of this case can be described as follows:

Let $|S| \geq 2$ be the set of available options, and $\mathrm{D}(\mathrm{S})$ is the subset of options given by the experimental design. There exists a $Y \in D(S)$ where $|Y| \geq 2$, and there is a choice of "best" represented in MNL terms by:

$$
B_{Y}(y)=\frac{e^{u(y)}}{\sum_{z \in Y} e^{u(z)}}
$$

\section{Probability of Best choice}

where $B_{Y}(y)$ represents the probability that attribute level $x$ will be chosen as best in $\mathrm{Y}$, assuming a scale $\mathrm{u}$ for each $y \in Y \in D(S)$. For the "worst" choice, the representation in MNL terms is:

$$
W_{Y}(y)=\frac{e^{v(y)}}{\sum_{z \in Y} e^{v(z)}}=\frac{e^{-u(y)}}{\sum_{z \in Y} e^{-u(z)}}
$$

\section{Probability of worst choice}

where $W_{Y}(y)$ represents the probability that an attribute level $x$ will be chosen as worst in $\mathrm{Y}$, assuming a scale $\mathrm{v}$ for each $y \in Y \in D(S)$. A theoretical argument for the case is $\mathrm{v}=-\mathrm{u}$ [29]. With this assumption, the probability that $y \in Y$ is chosen as best for u(z) where $z \in Y$ is equal to the probability that $y \in Y$ is chosen as worst for $-\mathrm{u}(\mathrm{z})$ where $z \in Y$. Accordingly, the utility value of an attribute level chosen as best is the negative value for that same attribute level when chosen as worst. 
The experimental design was a multi-factor categorical design performed in the StatgraphicsCenturion XVII software. We decided to apply the above design approach because this technique is suitable when the primary interest focuses on a comparison of levels of two or more categorical factors, such as BWS. The software creates a multilevel factorial design running each possible combination of the factor levels. In our case, we obtained 3,888 possible combinations according to the product between the number of levels of every attribute. We selected five sets, looking for variability in the attribute levels and ensuring the inclusion of all levels in at least one set. Table 2 presents the sets used in the survey, while Table 3 shows an example of the survey.

Table 2. The scenario presented to the participants

\begin{tabular}{ccccc}
\hline SET1 & SET 2 & SET 3 & SET 4 & SET 5 \\
\hline A2 & A1 & A1 & A1 & A1 \\
\hline B1 & B1 & B1 & B2 & B1 \\
\hline C1 & C1 & C2 & C1 & C1 \\
\hline D2 & D2 & D1 & D2 & D3 \\
\hline F2 & F1 & F1 & F1 & F1 \\
\hline G2 & G1 & G1 & G1 & G2 \\
\hline H1 & H2 & H1 & H2 & H1 \\
\hline I1 & I1 & I1 & I2 & I1
\end{tabular}

Source: Authors own elaboration.

Table 3. An example of the profile presented in the survey.

\begin{tabular}{|c|l|l|}
\hline Best (Most important) & \multicolumn{1}{|c|}{ Set 1 } & Worst (Less important) \\
\hline & $\begin{array}{l}\text { One damage or theft to the vehicle } \\
\text { every three months }\end{array}$ & \\
\hline & $\begin{array}{l}\text { One robbery registered every month } \\
\text { at the parking zone }\end{array}$ & \\
\hline & $\begin{array}{l}\text { The parking space is 1-5 minute walk } \\
\text { from the destination }\end{array}$ & \\
\hline & $\begin{array}{l}\text { Time finding available parking space is } \\
\text { between 3-6 minutes }\end{array}$ & \\
\hline & Sidewalks available & \\
\hline & $\begin{array}{l}\text { There is no element of protection } \\
\text { against sunshine or rain }\end{array}$ & \\
\hline $\mathrm{X}$ & $\begin{array}{l}\text { No demarcation: it is hard to recognize } \\
\text { the parking space and identify } \\
\text { circulation paths }\end{array}$ & \\
\hline Would you park inside the campus in these conditions? & $\begin{array}{l}\text { Free to USD 0.5/hour or fraction -USD } \\
\text { 3 all day }\end{array}$ & Yes_X_ No__ \\
\hline
\end{tabular}

Source: Authors own elaboration. 


\section{Modeling}

We performed the model estimation by specifying an MNL model. Attribute-specific constants form the utility function of each alternative attribute and therefore allow quantification of the attribute weight or importance in the parking lot facility choice. Each attribute level is a choice alternative in the model [28]. We used Biogeme 2.5 [30] to estimate the attribute-specific constants that, in turn, allow the estimation of the probability of choosing a specific attribute level in a given parking lot choice scenario.

The database also included the availability of each attribute level in every set and a choice variable. We used dummy variables to define the attribute level availability. The dummy variable was one when the attribute level was available in the set and zero otherwise. The choice variable contained the corresponding responses for the best and worst attributes within every set.

The software estimates the "utility" of each attribute level and their corresponding statistics (e.g., t-test and p-value). Those attribute levels not showing statistical significance were considered to be as important as walking time. Meanwhile, higher coefficients along with statistical significance suggest that attribute levels are more attractive for a specific parking choice behavior.

\section{Results}

The parking lot inventory shows that 107 spaces are available for use within the university campus influence area (see Table 4). Administrative staff and university founders have reserved $28 \%$ of those parking lots for their use (preassigned and unavailable for others even if they are empty). The parking turnover within the university campus is 4.82 , which can be considered high when compared to the 1.38 average parking turnover in the city according to Castellanos et al. [31].

One problem the university has is that there is no documentation or benchmark for commuters' mode of transportation to campus, which creates a huge uncertainty in how the parking lot operates, the behavior of cars through the day, peak and off-peak hours, among others. Therefore, in this work, we gathered information on-site by manually counting car arrivals and departures from 6:00 to 21:00 during three business days.

Table 4. Parking space information

\begin{tabular}{ccc}
\hline Parking Turnover & Parking spaces available & $\begin{array}{c}\text { Parking spaces per personnel } \\
\text { (administrative staff + students = 13420) }\end{array}$ \\
\hline $\mathbf{4 , 8 2}$ & 107 & 0.008 \\
\hline
\end{tabular}

Source: Authors own elaboration. 
Table 5 shows a summary of the BWS survey results. As shown, the respondents are mostly males in their $30 \mathrm{~s}$. Most of the respondents were staff (72\%), most belong to the upper to medium socioeconomic classes, and their income is higher than the minimum wage of the country, which was US\$270 for 2017.

Table 5. Summary of sample characteristics $(n=100)$

\begin{tabular}{lc}
\hline \multicolumn{1}{c}{ Characteristics } & $\mathbf{n = 1 0 0}$ \\
\hline Gender, male (\%) & $79(79 \%)$ \\
\hline Age (years), mean (SD) & $36(12)$ \\
\hline Role in the university: student \%, (staff \%) & $72(28)$ \\
\hline Household Income & 24 \\
\hline$\quad$ Less than USD 720 (\%) & 76 \\
\hline$\quad$ More than USD 721(\%) & 24 \\
\hline Low social class (1-2) (\%) & 56 \\
\hline Medium social class (3-4) (\%) & 20 \\
\hline High social class (5-6) (\%) & 94 \\
\hline Use frequency of the transportation mode chosen to travel to the university & 6 \\
\hline Motorized (\%) & \\
\hline Nonmotorized (\%)
\end{tabular}

Source: Authors own elaboration.

The walking time from the parking spaces within the campus to the buildings is approximately 1 to 5 minutes. However, walking times could be higher for parking outside the university campus. We chose the walking time variable as a base value due to its presence in most choice set scenarios and because the parking location is somewhat of an essential attribute for parking choice in warm weather such as that in Barranquilla.

Three models were estimated. The first denoted WPBC, which stands for "willing to park best choice." The WPBC model considers the best attribute selected by those respondents who are willing to park within the campus. The second model, called WPWC, stands for "willing to park worst choice." This second model considers the attribute selected as worst by those respondents willing to park within the campus. The third model, named NPBC, refers to the best attribute selected by those respondents who are not willing to park within campus. Table 6 presents the estimation results of the three considered models. 
Table 6. MNL model results

\begin{tabular}{|c|c|c|c|c|c|c|c|c|c|c|c|}
\hline \multicolumn{4}{|c|}{ Best (WPBC) } & \multicolumn{4}{|c|}{ Worst (WPWC) } & \multicolumn{4}{|c|}{ Best (NPBC) } \\
\hline Name & Estimate & t-test & p-value & Name & Estimate & t-test & p-value & Name & Estimate & t-test & p-value \\
\hline A1 & 6.90 & 3.71 & 0.00 & B1 & -9.92 & -4.46 & 0.00 & A1 & 11.70 & 6.22 & 0.00 \\
\hline I1 & 4.08 & 2.08 & 0.04 & A1 & -9.21 & -4.41 & 0.00 & B1 & 8.52 & 4.33 & 0.00 \\
\hline G1 & 3.23 & 3.25 & 0.00 & H1 & -2.67 & -2.98 & 0.00 & A2 & 3.20 & 5.4 & 0.00 \\
\hline B1 & 3.16 & 1.63 & 0.10 & $\mathbf{F 2}$ & -1.53 & -3.71 & 0.00 & G1 & 2.81 & 2.56 & 0.01 \\
\hline D2 & 1.28 & 1.20 & 0.23 & D2 & -1.44 & -2.02 & 0.04 & G2 & 1.29 & 1.51 & 0.13 \\
\hline A2 & 1.24 & 2.11 & 0.04 & G1 & -1.18 & -1.63 & 0.10 & I2 & 1.18 & 1.87 & 0.06 \\
\hline G2 & 0.71 & 0.90 & 0.37 & A2 & -1.14 & -1.67 & 0.09 & H1 & 0.05 & 0.03 & 0.97 \\
\hline F2 & 0.54 & 1.02 & 0.31 & I2 & -1.07 & -2.19 & 0.03 & F2 & -0.80 & -1.04 & 0.30 \\
\hline D1 & 0.46 & 0.59 & 0.56 & G2 & -0.18 & -0.34 & 0.73 & D2 & -0.99 & -0.64 & 0.52 \\
\hline I2 & -0.47 & -0.55 & 0.58 & D1 & -0.11 & -0.21 & 0.83 & I1 & -1.77 & -0.58 & 0.57 \\
\hline H1 & -1.37 & -0.99 & 0.32 & I1 & 0.39 & 0.32 & 0.75 & & & & \\
\hline $\mathrm{C} 1$ & 0 & fixed & & $\mathrm{C} 1$ & 0 & fixed & & $\mathrm{C} 1$ & 0 & Fixed & \\
\hline $\begin{array}{l}\text { Numb } \\
\text { observ }\end{array}$ & $\begin{array}{l}\text { of } \\
\text { tions: }\end{array}$ & & 59 & $\begin{array}{l}\text { Numb } \\
\text { obser }\end{array}$ & $\begin{array}{l}\text { r of } \\
\text { tions: }\end{array}$ & & 4 & $\begin{array}{l}\text { Numb } \\
\text { observ }\end{array}$ & $\begin{array}{l}\text { of } \\
\text { ions: }\end{array}$ & & 7 \\
\hline $\begin{array}{l}\text { Final } 1 \\
\text { likelih }\end{array}$ & & & .893 & $\begin{array}{l}\text { Final } \\
\text { likelih }\end{array}$ & & -33 & .915 & $\begin{array}{l}\text { Final I } \\
\text { likelih }\end{array}$ & & & .326 \\
\hline Rho-sc & lare: & & 70 & Rho-s & uare: & & 98 & Rho-s & are: & & \\
\hline
\end{tabular}

\section{Source: Authors}

The WPBC model shows that vehicle security is the most influential variable for parking behavior. This result was expected because of the insecurity rates in the city and the area surrounding the university and is in line with the suggestions made by Soto et al. [32], who suggest considering safety perception as a factor for parking choice; with this result, we confirm this statement. The second most relevant attribute is the parking fare, which highlights the importance of user sensitivity to cost variables. The third most important attribute is roof cover availability. Given the adverse weather conditions of the city, users prefer not to leave their vehicles exposed to sunlight or other weather conditions.

The attribute levels with the highest value in the WPWC model are B1 and A1, which represent user safety and vehicle security, respectively, which means that the user would park in these conditions; nevertheless, the safety and security conditions do worry them. The above result suggests that the most relevant attributes for parking choice are related to safety and security issues.

The NPBC model is useful because it provides information regarding the factors that determine not electing a parking lot within the university campus. In other words, it suggests which factors explain why users would not park in the campus parking facilities. The results can give the administration the opportunity to improve such factors. Vehicle safety (A1) and user safety (B1) take the highest values, in line with previous models. The other important factor is cover availability $(\mathrm{G})$, showing that it is a factor considered in the choice. 
A joint model considering both the best and worst choices for those respondents willing to park inside the campus was also estimated. The final log-likelihood of the joint model was 658.014. The adequacy of using a joint model was evaluated using an LR test [33] [34], but the result ( $\mathrm{LR}=-38.4$ ) suggests that there is asymmetry in the user's preferences. In this case, the best and worst choices cannot simply be merged using a scale factor, which is in line with other BWS applications [17]. The above means that data should be assessed independently for the best and for worst choices; mixing them in a joint model is not suggested.

The variable "wider parking spot" was not significant, which is in line with the results of Shaaban \& Pande [35], where this variable was also not a factor influencing parking choice. This is an interesting result given that parking managers think that providing a wider area, and hence easier and more comfortable parking spots, would attract customers, but given these results for two completely different countries (Colombia and Qatar), it is proven that wider space is a waste of space and money.

\section{Conclusions}

This paper applied the BWS approach to identify factors affecting user preferences for parking choices. We formulated and estimated three models to represent the most relevant attributes for two groups traveling to the university campus: those who currently park within the campus and those who currently park outside of campus.

The main objective of this work is to identify policies to implement based on the results to reduce university parking congestion. As almost every parking choice literature states, i.e., [1], [4], [9], [12], [32], [36], [37], pricing is the basic policy used to address parking congestion, so this should be implemented in the case study. The problem of how to define the parking fare is resolved based on the modeling results. Another policy that should be modified is that reserving spots for high positions and university founders; at the moment, $28 \%$ of the parking lot is unavailable due to this policy, greatly reducing the parking capacity (number of available spots inside the campus) considering that those spots are empty most of the time.

The most important attributes in all the models were those related to safety and security issues. According to the WPBC model, the primary factor for using private parking is the risk of auto theft in the zone surrounding the parking lot. Meanwhile, the NPWC model states that the most relevant factor in parking behavior is related to user security perception while walking from the parking lot to the final destination. These results apply to cities with similar security indexes. Based on this, the university should install security cameras and include more security staff in the area surrounding the campus. On the other hand, insecurity affects bicycle riders as much as walkers in university zones. It has been proven that improving walking and cycling safety conditions may reduce parking congestion by 5-15\% [5].

Roof cover availability is another relevant factor according to the modeling results. It is a striking result given that in other countries and cities, users would not consider this attribute 
as relevant because they leave cars parked even in snowing conditions, but it is in line with the results of a parking study in another hot city, Doha [35]. In Barranquilla, people believe that weathering could damage the car's body, even if it is just for a few hours. Additionally, the high temperatures developed inside of a parked car exposed to direct sunlight (which can reach $55^{\circ} \mathrm{C}$ [38]), force users to open the car doors and windows and wait for it to cool down before riding in it. Thus, it should be clear that the policy should be oriented to provide more roof coverage for vehicles and users and establishing "roof pricing" by charging extra for parking spots with roof cover.

According to WPBC, parking fare was identified as the second factor in parking choice. If the goal is to reduce parking congestion and vehicle usage, raising parking fares within campus is then a suitable policy. Currently, there is no parking fee on the university campus. Introducing a parking fare could help reduce the demand by approximately $10 \%$ to $30 \%$ [5]. Reductions in parking occupancy imply congestion reductions during peak hours and a possible higher market share for other transportation modes (e.g., transit, bicycle, walk). A dynamic pricing fare based on parking lot occupancy is suggested, complemented with an app that allows users to consult the current price. The app and the fare can lead users not willing to pay the fee to shift to sustainable modes; thus, the parking lot will be cheaper during off-peak hours and more expensive during peak hours.

The policies proposed to the university are removing the "reserved spots policy," implementing dynamic fare rates based on both parking demand and roof availability, improving security in the areas surrounding the campus and installing additional features such as parking spot detection technology and a phone app. Another way to reduce congestion is to encourage a modal shift towards bicycling, but in this particular case, they could start by improving the conditions and capacity of the bicycle parking lot.

The results presented in this paper can be applied to similar locations in the city and to other universities of similar size, social, economic and weather conditions. For future work, separating public parking spaces from private ones in the survey could give different measures of improvement, suggesting independent policies for each case. The BWS methodology proved to be valid for this type of problem and a simple yet practical approach for addressing parking congestion problems at universities.

\section{Acknowledgment}

We thank Universidad de la Costa for supporting this research and give us the space to apply the surveys in their campus. 


\section{References}

[1] W. Riggs, "Dealing with parking issues on an urban campus: The case of UC Berkeley," Case Studies on Transport Policy, vol. 2, no. 3, pp. 168-176, 2014.

[2] C.J. Balsas, "Sustainable transportation planning on college campuses," Transport Policy, vol. 10(1), p. 35-49, 2003.

[3] D. Shoup, Parking on smart campus: California Policy Options. Los Angeles: UCLA School of Public Affairs, 2005.

[4] A. Aoun et al., "Reducing parking demand and traffic congestion at the American University of Beirut," Transport Policy, vol. 25, pp. 52-60, 2013.

[5] T. Litman, "Evaluating parking management benefits," Transportation Research Board 2007 Annual Meeting, vol. 86, p. 14, 2007.

[6] C. Miralles-Guasch y E. Domene, "Sustainable transport challenges in a suburban university: The case of the Autonomous University of Barcelona," Transport Policy, vol. 17, pp. 454-463, 2010.

[7] J. Bilbao Ubillos. and A. Fernández Sainz, "The influence of quality and price on the demand for urban transport: the case of university students," Transportation Research Part A: Policy and Practice, vol. 38, no. 8, pp. 607-614, 2004.

[8] C. Gonzáles Calderón,D. Moreno Palacio, and S. Velásquez Gallón, "Análisis de la movilidad en campus universitarios: Caso de estudio Universidad de Antioquia," Revista Politécnica, vol. 7, no. 12, p. 4, 2011.

[9] V. Cantillo, Estudio de movilidad de la Universidad del Norte. Barranquilla: Universidad del Norte, 2012.

[10] A. Filipovitch, and E. Frimpong, "A systems model for achieving optimum parking eficiency on campus: The case of Minnesota State University,” Transport Policy, vol. 45, pp. 86-98, 2015.

[11] L.D. Olio, "Paying for parking: improving stated-preference surveys," Proc. of the Inst. of Civil Engineers Transport, vol. 162, no. TR1, pp. 39-45, 2009.

[12] S. Sultana, "Factors associated with students' parking-pass purchase decisions: Evidence from an American University," Transport Policy, vol. 44, pp. 65-75, 2015.

[13] X. Ma et al., "Parking choice behavior investigation: A case study at Beijing Lama Temple," Procedia - Social and Behavioral Sciences, vol. 96, pp. 2635-2642, 2013.

[14] J. Louvriere J., The best-worst or maximum difference measurment model: applications to behavioral research in marketing. Phoenix, Arizona, 1993.

[15] L.H. Mielby, M. Edelenbos, and A. K. Thybo, "Comparison of rating, best-worst scaling, and adolescents' real choices of snacks," Food Quality and Preference, vol. 25, no. 2, pp. 140-147, 2012.

[16] S. R. Jaeger, A.S. Jørgensen, M. D. Aaslyng, and W. L. Bredie, "Best-worst scaling: An introduction and initial comparison with monadic rating for preference elicitation with food products," Food Quality and Preference, vol. 19, pp. 579-588, 2008. 
[17] A. Larrañaga, J. Arellana, L. Rizzi, O. Strambi and H. Cybis, "Using Best-Worst Scaling to identify barriers to walkability: a study of Porto Alegre, Brazil," Transportation, pp. 1-33, 2018.

[18] M.R. Franco et al, "Eliciting older people's preferences for exercise programs: A best-worst scaling choice experiment," Journal of Physiotherapy, vol. 61, no. 1, pp. 34-41, 2015.

[19] C.J. Lagerkvist, "Consumer preferences for food labelling attributes: Comparing direct ranking and best-worst scaling for measurement of attribute importance, preference intensity and attribute dominance," Food Quality and Preference, vol. 29, no. 2, pp. 77-88, 2013.

[20] C. Balbontin, J.D.D. Ortuzar, and J.D. Swait, "Importance of dwelling and neighbourhood attributes in residential location modelling: best worst scaling vs . discrete choice," Procedia Social and Behavioral Sciences, vol. 160, pp. 92-101, 2014.

[21] J. J. Cabello, M. Orozco, C. Ayala, H. Hernández, and P. Romero, "Evaluación de la calidad de vida urbana en las principales ciudades colombianas," Revista Brasileira de Gestão e Desenvolvimento Regional, pp. 106-127, 2017.

[22] D. Bostyn and A. Roets, "The morality of action: The asymmetry between judgments of praise and blame in the action-omission effect," Journal of Experimental Social Psychology, vol. 63, pp. 19$25,2016$.

[23] G. Feldman, K.F.E. Wong, and R.F. Baumeister, "Bad is freer than good: positive-negative asymmetry in attributions of free will," Conscious. Cogn., vol. 42, 2016.

[24] D.L. Hamilton and M.P. Zanna, "Differential Weighting of Favorable and Unfavorable Attributes in," Journal of Experimental Research in Personality, vol. 6, no. 2-3, pp. 204-212, 1972.

[25] A. Tversky and D. Kahneman, "Advances in prospect theory: cumulative representation of uncertainty," Journal of Risk and Uncertainty, vol. 5, pp. 297-323, 1992.

[26] I. Kittelson \& Associates and P. Brinckerhoff, Transit Capacity and Quality of Service Manual, 3rd ed., Washington D.C., 2013.

[27] CEPAL, ¿Solidaridad ofocalización?: la estratificación socioeconómica para el cobro de los servicios públicos domiciliarios en Colombia, Santiago, 2006.

[28] T.N. Flynn, and A.A.J. Marley, Best Worst Scaling: Theory and Methods. Australia, 2007.

[29] A.A.J. Marley, and J.J. Louviere, "Some probabilistic models of best, worst, and best - worst choices," Journal of Mathematical Psychology, vol. 49, pp. 464-480, 2005.

[30] M. Bierlaire, "BIOGEME: A free package for the estimation of discrete choice models," Proc. 3rd Swiss Transportation Research Conference, Ascona, Switzerland, 2003.

[31] N. Castellanos, A. Sánchez, and A. Zarate, Estudio de estacionamiento sobre la vía y en lotes privados en el área de influencia del centro expandido de Barranquilla. Barranquilla: Universidad Nacional de Colombia, 2005.

[32] J. J. Soto, L. Márquez, and L. F. Macea, "Accounting for attitudes on parking choice: An integrated choice and latent variable approach," Transportation Research, Part A, 2018.

[33] M. Ben-Akiva and S. Lerman, Discrete choice analysis: theory and application to travel demand. Boston: MIT Press, 1985. 
[34] J. de D. Ortuzar and L. Willumsen, Modelling Transport. New York: Wiley, 2011.

[35] K. Shaaban and A. Pande, "Classification tree analysis of factors affecting parking choices in Qatar," Case Studies on Transport Policy, vol. 4, no. 2, pp. 88-95, 2016.

[36] E. Barata, L. Cruz, and J. Ferreira, "Parking at the UC campus: Problems and solutions," Cities, vol. 28, no. 5, pp. 406-413, 2011.

[37] A. Ibeas, L. dell'Olio, M. Bordagaray, and J. de D. Ortúzar, "Modelling parking choices considering user heterogeneity," Transportation Research Part A: Policy and Practice, vol. 70, pp. 41-49, 2014.

[38] RACC, "Efecto de la radiación solar en la temperatura interior del vehículo," 2015 [onlines]. Available: http://s01.s3c.es/imag/doc/2015-08-06/estudio-sol-coche-racc.pdf 